\title{
Prevalence of the paa gene (porcine attaching and effacing associated) in porcine enteropathogenic Escherichia coli (PEPEC) associated with postweaning diarrhea in south Brazil
}

\author{
Marilda C. Vidotto ${ }^{1}$, Elaine C.T. Florian ${ }^{3}$, Mario A. Ono ${ }^{2}$ \\ ${ }^{1}$ Departamento de Medicina Veterinária Preventiva, \\ Universidade Estadual de Londrina, Londrina, PR, Brazil. \\ ${ }^{2}$ Departamento de Ciencias Patológicas, Universidade Estadual de Londrina, \\ Londrina, PR, Brazil. \\ ${ }^{3}$ Departamento de Bioquímica e Biotecnologia, \\ Universidade Estadual de Londrina, Londrina, PR, Brazil.
}

Submitted: October 17, 2011; Approved: July 23, 2012.

\begin{abstract}
Paa (porcine attaching and effacing associated) may be an important virulence factor $E$. coli of piglets with diarrhea. This study showed for the first time in Brazil the prevalence of the paa gene (22\%) in E. coli strains isolated from piglets and these isolates also harboured genes for other adhesins and toxins LT II, STa and STb.
\end{abstract}

Key words: Escherichia coli, pig, PEPEC, paa gene, postweaning diarrhea.

Neonatal diarrhea and postweaning diarrhea (PWD) in pigs are diseases of considerable economic importance and are characterized by watery diarrhea, dehydration, loss of body weight and sometimes death of infected pigs (Nagy and Fekete, 1999). Enterotoxigenic E. coli (ETEC) is an important cause of PWD, and its pathogenicity involves the adherence of the pathogen to the small intestine by means of specific adhesion factors (fimbriae) and production of one or several exotoxins responsible for disease development. ETEC produce heat-stable (Sta or Stb) and/ or heatlabile (LT) enterotoxin that cause fluid and electrolyte secretion (Nagy and Fekete, 1999)

However, non-enterotoxigenic porcine E. coli strains have been associated with PWD and neonatal diarrhea in swine by adhesion to intestinal epithelial cells in a characteristic attaching and effacing $(\mathrm{A} / \mathrm{E})$ pattern. This porcine enteropathogenic E. coli (PEPEC) produces an outer membrane protein (intimin), which is involved in the intimate attachment of the bacteria to enterocytes and induced typical $\mathrm{A} / \mathrm{E}$ lesion in a pig ileal explant model (Zhu et al., 1994, 1995). The A/E lesion contributes to the initial phases of PEPEC pathogenicity (Batisson et al., 2003).
The gene that induces this lesion was designated paa (porcine A/E-associated gene) (Nagy and Fekete, 1999; An et al., 1999), and its sequence revealed an open reading frame of $753 \mathrm{bp}$ encoding a $27.6 \mathrm{kDa}$ protein, that shows similarity with Paa of enterohemorrhagic E. coli $\mathrm{O} 157: \mathrm{H} 7$ strains (Batisson et al., 2003). The A/E activity of PEPEC is highly correlated with the presence of the LEE (locus of enterocyte effacement) detected by DNA probes derived from the LEE of human enteropathogenic E. coli (EPEC) strain E2348/69 (An et al., 2000).

In Brazil there is a lack of information about the prevalence of the paa gene of porcine $E$. coli. The objective of the present study was to evaluate the presence of paa gene, and its correlation with the presence of enterotoxin STa, $\mathrm{STb}$ and LT encoding genes of $E$. coli strains isolated from piglets with diarrhea in Northern region of Paraná State, Brazil, described in a previous study (Vidotto et al., 2009).

Three hundred Escherichia coli strains isolated from 100 piglets with diarrhoea from different farms in Paraná State (Vidotto et al., 2009) were tested for the presence of the paa gene by polymerase chain reaction assay (PCR). The E. coli HB101strain (Boyer and Roulland-Dssoix, 1969) was included as negative control.

Send correspondence to M.C. Vidotto. Departamento de Medicina Veterinária Preventiva, Universidade Estadual de Londrina, Campus Universitário, Caixa Postal 6001, 86051-970 Londrina, PR, Brazil. E-mail: macarlos@uel.br. 
The base sequences for specific oligonucleotide primers used in this study were constructed based on the regions of conserved sequences between the paa gene of ETEC and PEPEC 045 (GeneBanK U82533.4), PAA PEPEC O45-F: 5'- TCTTCTGCTGCTTATGCTGATA TC-3' and PAA PEPEC O45-R: 5'- TTACCAGCCATA TTTTTTGAATGC-3', annealing at nucleotides 37 to 60 and 718 to 738 of the paa gene, respectively. Bacterial DNA to be amplified was released from whole organisms by boiling, and PCR was carried out in a total volume of $25 \mu \mathrm{L}$ containing $5 \mu \mathrm{L}$ template DNA, each of the primers at $20 \mathrm{pmol}, 200 \mu \mathrm{M}$ dNTPs, PCR buffer and $1.5 \mathrm{U}$ Taq DNA polymerase (Invitrogen). PCR amplifications consisted of 30 cycles of $94{ }^{\circ} \mathrm{C}$ for $1 \mathrm{~min}$, annealing temperature specific for each primer for $1 \mathrm{~min}$ and $72^{\circ} \mathrm{C}$ for $2 \mathrm{~min}$. The amplified DNA was visualized in $1.5 \%$ agarose gels stained with ethidium bromide. The 100-pb ladder (Promega, Madison, WI) was used as standard.

Of 100 piglets with diarrhea, $22 \%$ presented E. coli that carried paa genes. The presence of the paa gene (Table 1) was correlated with the presence of genes that encode fimbrial adhesins F4, F5, F6, F18, F41 and the toxins LT II, $\mathrm{STa}$ and STb found in these studied strains (Vidotto et al., 2009). Some strains that carried the paa gene also harboured genes for others adhesins and toxins (Table 1). There was no significant association of paa gene with the other virulence genes when analyzed by chi-square test $(\mathrm{p}>0.05)$.
The presence of ETEC virulence factors, fimbriae and enterotoxins production, are common features of isolates associated with diarrhea during the pre-weaning and weaning periods (Nagy and Fekete, 1999, 2005), but some E. coli strains isolated from piglets with diarrhea were non-enterotoxigenic, and presented intimin ( sponsible for A/E lesions (Zhu et al., 1995). The serogroup O45 is particularly important among PEPEC strains, and based on their virulence gene content, O45 PEPEC strains displayed significant differences from typical EPEC and could be regarded as atypical EPEC, that are defined as LEE-positive $E$. coli lacking $s t x 1$ and stx 2 genes (Bruant $e t$ al., 2009).

In the present study, the paa gene was detected in $22 \%$ of $E$. coli isolated from diarrhoeic piglets, from the Northern Region of Paraná State, and this gene was associated with other virulence factors from ETEC. We found the paa gene in isolates that carried additional virulence encoding genes such as faeG (F4), fanC (F5), fasA (F6), fedA (F18), f41, estA (STa), estB (STb) and elt (LT). The pathotype $\mathrm{F}^{+} \mathrm{F}_{18}^{+} \mathrm{F}^{+} 1^{+} \mathrm{Paa}^{+} \mathrm{STa}^{+} \mathrm{STb}^{+}$and $\mathrm{LT}^{+}$were found among the strains. These data suggest that the various virulence genes together can be link to resistance genes on plasmids. The paa gene was found on high molecular weight plasmids that codify tetracycline resistance (Leclerc et al., 2007).

Similarly Leclerc et al. (2007) found the paa gene with virulence genes associated with pig ETEC, estA that encodes $\mathrm{STa}$, estB that encodes $\mathrm{STb}$, elt that encodes LT, astA that encodes EAST1 and faeG that is a part of the F4

Table 1 - Distribution of the paa gene and enterotoxins among E. coli strains isolated from diarrheic piglets.

\begin{tabular}{|c|c|c|c|c|c|c|c|}
\hline Adhesins & $\mathrm{N}^{\mathrm{o}}$ of strains & $\mathrm{STb}$ & LT & STa LT & $\mathrm{STb} \mathrm{LT}$ & STa STb LT & None toxin \\
\hline Paa & 2 & & & & & & 2 \\
\hline $\mathrm{Paa}$ & 3 & & 3 & & & & \\
\hline $\mathrm{Paa}$ & 2 & & & & 2 & & \\
\hline Paa & 1 & 1 & & & & & \\
\hline $\mathrm{Paa}+\mathrm{F} 6$ & 1 & & & 1 & & & \\
\hline $\mathrm{Paa}+\mathrm{F} 41$ & 1 & & & & & 1 & \\
\hline $\mathrm{Paa}+\mathrm{F} 4+\mathrm{F} 5$ & 1 & & 1 & & & & \\
\hline $\mathrm{Paa}+\mathrm{F} 5+\mathrm{F} 18$ & 1 & 1 & & & & & \\
\hline $\mathrm{Paa}+\mathrm{F} 4+\mathrm{F} 6+\mathrm{F} 18$ & 2 & & & 1 & & 1 & \\
\hline $\mathrm{Paa}+\mathrm{F} 4+\mathrm{F} 18+\mathrm{F} 41$ & 1 & & & & & 1 & \\
\hline $\mathrm{Paa}+\mathrm{F} 5+\mathrm{F} 18+\mathrm{F} 41$ & 1 & & & 1 & & & \\
\hline $\mathrm{Paa}+\mathrm{F} 4+\mathrm{F} 5+\mathrm{F} 6+\mathrm{F} 41$ & 1 & & & & & & 1 \\
\hline $\mathrm{Paa}+\mathrm{F} 4+\mathrm{F} 6+\mathrm{F} 18+\mathrm{F} 41$ & 2 & 1 & & & 1 & & \\
\hline $\mathrm{Paa}+\mathrm{F} 4+\mathrm{F} 5+\mathrm{F} 18+\mathrm{F} 41$ & 1 & & & & & 1 & \\
\hline $\mathrm{Paa}+\mathrm{F} 4+\mathrm{F} 5+\mathrm{F} 6+\mathrm{F} 41$ & 2 & & & & & 2 & \\
\hline Total & 22 & 3 & 4 & 3 & 3 & 6 & 3 \\
\hline
\end{tabular}

Paa- porcine A/E lesion-associated adhesin, F4- K88, F5- K99, F6-987P.

LT-thermolabile enterotoxin, ST-termostable enterotoxin.

No statistically significant association detected. 
operon. The occurrence of enterotoxins was also associated with specific fimbriae in E. coli from pigs and several strains produced more than one fimbrial antigen (Nagy and Fekete, 2005; Toledo et al., 2012; Vidotto et al., 2009).

The prevalence of the paa gene $(22 \%)$ found in this study was different than that found by others, Zhang et al. (2007) found a prevalence of $60 \%$ in E. coli strains isolated from young pigs with diarrhea in the US, and Boerlin et al. (2005) detected paa in $92 \%$ of porcine ETEC isolated in Canada.

The paa gene sequence is similar to that of the EPEC eae gene that codifies intimin (Zhu et al., 1994), and the eae gene also have been found in $25.7 \%$ of isolates in Brazil (Martins et al., 2000), 28.33\% in China (Cheng et al., 2006); and 27\% of isolates in Mexico (Toledo et al., 2012).

In conclusion, this study showed for the first time in Brazil the prevalence of the paa gene in E. coli strains isolated from piglets with diarrhea, and confirms the combination of various virulence genes in ETEC and porcine EPEC, suggesting that the paa gene could play a role in virulence.

\section{Acknowledgments}

We thank Dra. Ana Vergínia Libos Messetti and Dra. Vanderli Marino Melem for statistical analysis. This work was supported by "Conselho Nacional de Desenvolvimento Científico e Tecnológico” (CNPq).

\section{References}

An H, Fairbrother JM, Desautels C, Harel J (1999) Distribution of a novel locus called Paa (porcine attaching and effacing associated) among enteric Escherichia coli. Adv Exp Med Biol 473:179-184.

An H, Fairbrother JM, Desautels C, Mabrouk T, Dugourd D, Dezfulian H, Harel J (2000) Presence of the LEE (locus of enterocyte effacement) in pig attaching and effacing Escherichia coli and characterization of eae, espA, espB and espD genes of PEPEC (pig EPEC) strain 1390. Microb Pathog 28:291-300.

Batisson I, Guimond MP, Girard F, An H, Zhu C, Oswald E, Fairbrother JM, Jacques M, Harel J (2003) Characterization of the novel factor paa involved in the early steps of the adhesion mechanism of attaching and effacing Escherichia coli. Infect Immun 71:4516-4525.

Boerlin P, Travis R, Gyles CL, Reid-Smith R, Janecko N, Lim H, Nicholson V, McEwen SA, Friendship R, Archambault M
(2005) Antimicrobial resistance and virulence genes of Escherichia coli isolates from swine in Ontario. Appl Envir Microbiol 71:6753-6761.

Boyer H, Roulland-Dssoix J (1969) A complementation analysis of the restriction and modification of DNA in E. coli. J Mol Biol 41:459-472.

Bruant G, Zhang Y, Garneau P, Wong J, Laing C, Fairbrother JM, Gannon VPJ, Harel J (2009) Two distinct groups of porcine enteropathogenic Escherichia coli strains of serogroup O45 are revealed by comparative genomic hybridization and virulence gene microarray. BMC Genomics 009 10:402.

Cheng D, Sun H, Xu J, Gao S (2006) PCR detection of virulence factor genes in Escherichia coli isolates from weaned piglets with edema disease and/or diarrhea in China. Vet Microbiol 115:320-328.

Leclerc S, Boerlin P, Gyles C, Dubreuil JD, Mourez M, Fairbrother JM, Harel J (2007) paa, originally identified in attaching and effacing Escherichia coli, is also associated with enterotoxigenic E. coli. Res Microbiol 158:97-104.

Martins MDF, Martinez-Rossi NM, Ferreira A (2000) Pathogenic characteristics of Escherichia coli strains isolated from newborn piglets with diarrhea in Brazil. Vet Microbiol 76:51-59.

Nagy B, Fekete PZ (1999) Enterotoxigenic Escherichia coli (ETEC) in farm animals. Vet Res 30:259-284.

Nagy B, Fekete PZ (2005) Enterotoxigenic Escherichia coli in veterinary medicine. Int J Med Microbiol 295:443-454.

Toledo A, Gómez D, Cruz C, Carreón R, López J, Giono S, Castro AM (2012) Prevalence of virulence genes in Escherichia coli strains isolated from piglets in the suckling and weaning period in Mexico. J Med Microbiol. 61:148-56.

Vidotto MC, Lima NCS, Fritzen TTJ, Freitas JC, Venâncio EJ, Ono MA (2009) Frequency of virulence genes in Escherichia coli strains isolated from piglets with diarrhea in the North Parana State, Brazil. Braz J Microbiol 40:199-204.

Zhang W, Zhao M, Ruesch L, Omot A, Francis D (2007) Prevalence of virulence genes in Escherichia coli strains recently isolated from young pigs with diarrhea in the US. Vet Microbiol 123:145-152.

Zhu C, Harel J, Jacques M, Desautels C, Donnenberg MS, Beaudry M, Fairbrother JM (1994) Virulence properties and attaching-effacing activity of Escherichia coli $\mathrm{O} 45$ from swine postweaning diarrhea. Infect Immun 62:4153-4159.

Zhu C, Harel J, Jaques M, Fairbrother JM (1995) Interaction with pig ileal explants of Escherichia coli O45 isolated from swine with postweaning diarrhea. Can J Vet Res 59:118-123.

All the content of the journal, except where otherwise noted, is licensed under a Creative Commons License CC BY-NC. 